\title{
Analisis Peluang Penyertaan Modal Pemerintah Daerah Kota XYZ pada PT Bank Jawa Barat dan Banten (Bank BJB)
}

\author{
Dian Yudo Palupi \\ Alumni Departemen Manajemen, Fakultas Ekonomi dan Manajemen \\ Institut Pertanian Bogor \\ Farida Ratna Dewi \\ Departemen Manajemen, Fakultas Ekonomi dan Manajemen \\ Institut Pertanian Bogor \\ Email: reida_05@yahoo.com \\ R. Dikky Indrawan \\ Departemen Manajemen, Fakultas Ekonomi dan Manajemen \\ Institut Pertanian Bogor \\ Email: rdikky@yahoo.com
}

\begin{abstract}
Economic growth and public welfare are the reason of regional autonomy regulation policy (UU No 22 year 1999). The policy allows regional economic resources managed by regional government to achieve its goal. One of the regional government strategies is investment strategy, which in this case investing in banking industry. The purposes of the study are 1) to identify the investment regulation on regional government 2) to identify the Bank BJB business and investment environment 3) to identify the comparison of investment feasibility on Bank BJB versus other banks 4) to identify the position of Stock Share A series owned by XYZ at Bank BJB. The data collection methods are using structured interview, in depth interview, field survey and literature study. The analysis tools are using institutional analysis, SWOT analysis and financial analysis. Institutional analysis showed XYZ regional government investment management is limited to regulation as follow 1) long term capital (stock share) investment limited only at BUMD (e.g. Bank BJB) 2) short term investment e.g. saving and deposit is limited only at healthy and feasible bank, and government bond which has small risk exposure. The financial analysis also showed the increasing performance of BJB Earning per Share (EPS) and Return on Equity (ROE) from 2006 until 2010. The SWOT analysis support other analysis that BJB Bank position in financial industry is suitable for long term and short term investment for $X Y Z$ regional government. Base on explanation above, the conclusions are the autonomy regulation limited $X Y Z$ regional government to invest as shareholders in A series (stock share) or B series (stock share) at BJB Bank only, and for short term investment is limited only at healthy and feasible bank, and government bond which has small risk exposure.
\end{abstract}

Key words: Investment, shares and bank 


\section{Pendahuluan}

Kota XYZ merupakan kota yang mulai berkembang dan menjadi penyangga (buffer) yang menerima dampak pertumbuhan ekonomi wilayah di sekitarnya. Laju pertumbuhan ekonomi dan jumlah penduduk Kota XYZ semakin meningkat dari tahun ke tahun. Dengan demikian, XYZ berkembang menjadi kota yang potensial dan strategis dalam kegiatan sosial dan ekonomi. Penyelenggaraan fungsi pemerintahan tentunya akan terlaksana secara optimal apabila diikuti dengan pemberian sumbersumber penerimaan yang cukup kepada daerah, dengan mengacu kepada UndangUndang tentang Desentralisasi Fiskal (UU No. 25 tahun 1999), di mana besarnya disesuaikan dan diselaraskan dengan pembagian kewenangan antara Pusat dan Daerah. Daerah diberikan hak untuk mendapatkan sumber keuangan, di antaranya melalui "hasil pengelolaan kekayaan daerah yang dipisahkan" yang bersumber dari bagian laba BUMD maupun hasil kerja sama dengan pihak ketiga.

Salah satu tujuan dari pemberian otonomi kepada daerah (UU No. 22 tahun 1999) di antaranya adalah untuk mendorong pertumbuhan ekonomi masyarakat yakni mempercepat terwujudnya kesejahteraan masyarakat sesuai dengan potensi dan keanekaragaman sumber daya lokal yang dimiliki oleh wilayah tersebut. Berdasarkan undang-undang tersebut, pemerintah daerah tentunya dituntut untuk lebih kreatif dan inovatif dalam membangun daerahnya serta memiliki daya saing tinggi dengan mengombinasikan antara faktor kondisi ekonomi, kualitas kelembagaan publik, sumber daya manusia dan teknologi yang secara keseluruhan membangun kemampuan daerah untuk lebih berkembang dan berdaya saing (UU No. 32 tahun 2004). Salah satu otonomi, yakni dengan penyertaan modal terhadap BANK BJB daerah yang dilakukan oleh Pemerintah Kota XYZ ini diaplikasikan pada sektor perbankan, karena berdasarkan data Biro Riset InfoBank, industri perbankan menguasai 90,46 persen pangsa pasar keuangan di Indonesia.

Pada tanggal 8 Juli 2010 Bank Jabar Banten secara resmi mencatatkan sahamnya di Bursa Efek Indonesia (BEI). Bank Jabar Banten telah berhasil mengukir prestasi sebagai Bank Pembangunan Daerah pertama yang telah melakukan penawaran perdana saham (IPO) kepada publik. Dengan terjadinya hal ini, maka terjadi juga perubahan komposisi kepemilikan saham pada BANK BJB.

Bank Jabar Banten menawarkan saham kepada publik sejumlah 2.424.072.500 lembar saham Seri B, termasuk EMSA (karyawan dan nasabah) dengan harga penawaran Rp600/lembar saham dengan dana yang diperoleh dari IPO sekitar Rp1,4 triliun. Pelepasan saham ke masyarakat ini setara dengan $25 \%$ dari jumlah modal ditempatkan dan disetor penuh Bank Jabar Banten. Perubahan struktur modal pada Bank BJB menjadi pertimbangan yang harus dilakukan oleh pemerintah daerah, terutama Pemerintah Kota XYZ terkait dengan penyertaan modal untuk seterusnya. Tentunya untuk melakukan penyertaan modal tersebut diperlukan kejelian, ketajaman dan keakuratan daya analisis dari aparat daerah. Berkaitan dengan kondisi tersebut, maka analisis mengenai penyertaan modal Pemerintah Daerah Kota XYZ kepada pihak ketiga (baik Bank BJB maupun produk pesaingnya) perlu untuk dilakukan. Perubahan status hukum Bank BJB sebagai Perseroan Terbatas, mengakibatkan berubah pula otonomi saham Bank BJB yang pada awalnya saham pemerintah mutlak $100 \%$ menjadi 75\%, dan 25\% dimiliki oleh masyarakat umum. Dengan kondisi ini Pemerintah Daerah 
Kota XYZ perlu mengidentifikasi apakah penyertaan modal terhadap Bank BJB masih layak atau tidak.

Oleh karena itu, permasalahan yang dapat dirumuskan dalam penyertaan modal oleh Kota XYZ ini adalah sebagai berikut: 1) Bagaimana peraturan perundangundangan terhadap penyertaan modal Pemerintah Daerah XYZ? 2) Bagaimana kondisi lingkungan internal dan eksternal Bank BJB dalam industri perbankan saat ini? 3) Bagaimana kelayakan investasi Pemerintah Daerah XYZ di Bank BJB dibandingkan dengan bank lainnya, serta produk perbankan lainnya? 4) Bagaimana posisi keadaan saham seri A yang dimiliki oleh Pemerintah Kota XYZ pada Bank BJB.

Adapun tujuan dari penulisan ini adalah: 1) Menganalisis peraturan perundangundangan terhadap penyertaan modal Pemerintah Daerah XYZ. 2) Menganalisis kondisi lingkungan internal dan eksternal Bank BJB yang dipengaruhi perbankan lainnya. 3) Menganalisis kelayakan investasi Pemerintah Daerah XYZ di Bank BJB dibandingkan dengan bank lainnya, serta produk perbankan lainnya. 4) Menganalisis posisi keadaan saham seri A yang dimiliki oleh Pemerintah Kota XYZ pada Bank BJB

\section{Metode Penelitian}

Penelitian penyusunan rencana penyertaan modal Pemerintah Kota XYZ terdiri dari lima tahapan. Kelima tahapan tersebut digambarkan sebagai berikut:

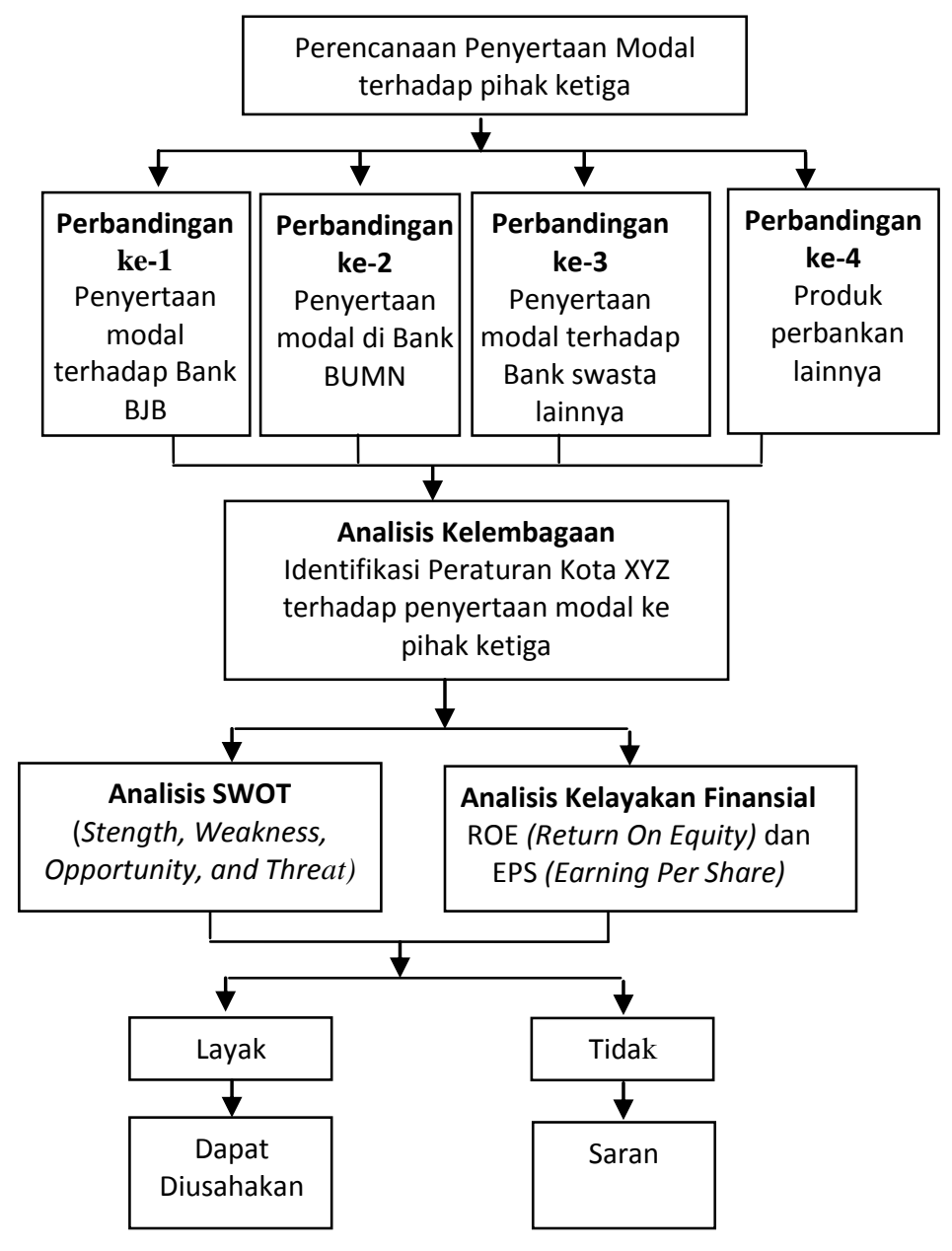

Gambar 1. Kerangka Pemikiran Penelitian 
Penelitian ini dilakukan dalam waktu tiga bulan (November 2010-Januari 2011) pada Pemerintah Kota XYZ dan PT Bank Jabar Banten XYZ.

Data yang digunakan dalam penelitian adalah data primer dan data sekunder yang bersifat kualitatif maupun kuantitatif. Data primer adalah data yang diperoleh langsung dengan cara observasi atau pengamatan, wawancara, kuisioner, dan opini pakar. Data sekunder diperoleh dari buku, internet, jurnal, Bursa Efek Indonesia (BEI), dan dokumen-dokumen pendukung lainnya.

Metode pengumpulan data yang digunakan dalam penelitian adalah:

1. Survei lapangan yaitu pengamatan langsung objek penelitian dengan tujuan untuk memahami kondisi lapangan yang sebenarnya.

2. In depth interview dilakukan kepada pihak-pihak yang terkait dengan rencana umum penyertaan modal, yaitu Bank Jabar Banten dan pihak Pemerintah Daerah Kota XYZ.

3. Kuesioner berisi daftar pertanyaan yang ditujukan kepada Bank Jabar Banten dan pihak Pemerintah Daerah Kota XYZ.

4. Studi literatur dilakukan dengan mengumpulkan data sekunder untuk diolah lebih lanjut.

Metode analisis yang digunakan adalah Analisis Kelembagaan, Analisis SWOT, dan Analisis Finansial. Analisis Kelembagaan bertujuan untuk mengetahui peraturan perundangan-undangan Republik Indonesia baik yang mendukung dan menghambat penyertaan modal Pemerintah Daerah Kota XYZ pada PT. Bank Jabar Banten (BANK BJB). Peraturan Republik Indonesia seperti Peraturan Pemerintah Dalam Negeri dan peraturan lainnya yang berkaitan dengan penyertaan modal dan dijadikan pedoman antara lain:

a. Peraturan Pemerintah Republik Indonesia Nomor 58 tahun 2005 tentang Pengelolaan Keuangan Daerah

b. Peraturan Menteri Dalam Negeri Nomor 13 Tahun 2006 tentang Pedoman Pengelolaan Keuangan Daerah

c. Peraturan Pemerintah Republik Indonesia Nomor 105 Tahun 2000 tentang Pengelolaan dan Pertanggungjawaban Keuangan Daerah.

Analisis SWOT adalah evaluasi terhadap keseluruhan kekuatan, kelemahan, peluang, dan ancaman perusahaan. Umumnya unit bisnis harus memantau kekuatan lingkungan makro yang menjadi penentu (demografi-ekonomi, teknologi, politikhukum, dan sosial-budaya), dan pelaku lingkungan mikro utama (pelanggan, pesaing, saluran distribusi, dan pemasok) yang berdampak pada kemampuannya memperoleh laba (Kotler, 2005).

Analisis Finansial bertujuan untuk mengetahui profitabilitas dan kelayakan penyertaan modal oleh Pemerintah Daerah Kota XYZ pada Bank Jabar Banten. Pada penelitian ini untuk mengetahui kelayakan finansial Bank Jabar Banten digunakan kriteria (ROE) Return on Equity dan (EPS) Earning Per Share.

Tingkat pengembalian ekuitas (ROE) yakni seberapa baik manajer perusahaan memaksimalkan kekayaan pemegang saham. ROE adalah sebuah ukuran dari besarnya jumlah laba dari sebuah perusahaan yang dihasilkan dalam 1 tahun terakhir dibandingkan dengan nilai ekuitasnya. 
ROE $=$

Pendapatan Bersih

Ekuitas pemegang Saham Biasa

EPS merupakan alat analisis tingkat profitabilitas perusahaan yang menggunakan konsep laba konvensional. EPS adalah salah satu dari dua alat ukur yang sering digunakan untuk mengevaluasi saham biasa di samping (PER) Price Earning Ratio dalam lingkaran keuangan.

EPS atau laba per lembar saham adalah tingkat keuntungan bersih untuk tiap lembar sahamnya yang mampu diraih perusahaan pada saat menjalankan operasinya. Laba per lembar saham atau EPS di peroleh dari laba yang tersedia bagi pemegang saham biasa dibagi dengan jumlah rata-rata saham biasa yang beredar. Rumus yang digunakan adalah sebagai berikut:

$$
\text { EPS }=\frac{\text { Laba Bersih Setelah Pajak dan Bunga }}{\text { Saham yang Beredar }}
$$

Menurut Heizer dan Render (2006), keakuratan keseluruhan dari setiap model peramalan dapat dijelaskan dengan membandingkan nilai yang diramal dengan nilai aktual atau nilai yang sedang diamati. Ada beberapa perhitungan yang biasa digunakan untuk menghitung kesalahan peramalan (forecast error) total.

Perhitungan ini dapat digunakan untuk membandingkan model peramalan yang berbeda, juga untuk mengawasi peramalan, untuk memastikan peramalan berjalan dengan baik. Besar kesalahan suatu peramalan dapat dihitung dengan beberapa cara, antara lain adalah :

1. MAD (Mean Absolute Deviation), mengukur ketepatan nilai dugaan model yang dinyatakan dalam bentuk rata-rata absolut kesalahan.

$$
M A D=\frac{\mid \text { aktual-peramalan } \mid}{\mathrm{n}}
$$

2. MSD (Mean Squarred Deviation), mengukur ketepatan nilai dugaan model yang dinyatakan dalam rata-rata kuadrat dari kesalahan.

MSD $=\frac{\text { aktual- }_{\text {peramalan }}^{2}}{\mathrm{n}}$

\section{MAPE (Mean Absolute Percentage Error)}

Masalah yang terjadi dengan MAD dan MSD adalah bahwa nilai mereka tergantung pada besarnya unsur yang diramal. Jika unsur tersebut dihitung dalam satuan ribuan, maka nilai MAD dan MSE bisa menjadi sangat besar. Untuk menghindari masalah ini, dapat menggunakan MAPE. MAPE digunakan untuk mengukur ketepatan nilai dugaan model yang dinyatakan dalam bentuk rata-rata persentase absolute kesalahan.

$$
\text { MAPE }=\frac{100 \quad \mathrm{n}_{\mathrm{i}=1} \frac{\mathrm{aktual}_{\mathrm{i}}-\mathrm{ramalan}_{\mathrm{i}}}{\text { aktual }_{i}}}{\mathrm{n}}
$$




\section{Hasil Penelitian}

III.1. Analisis Kelembagaan

Berdasarkan analisis peraturan-peraturan yang berkaitan dengan penyertaan modal dapat disimpulkan bahwa Pemerintah Daerah dapat melakukan penyertaan modal jika jumlah yang akan disertakan telah ditetapkan sebelumnya pada peraturan daerah pada tahun anggaran dan jika APBD mengalami surplus yakni anggaran pendapatan daerah diperkirakan lebih besar dari anggaran belanja daerah.

Analisis kelembagaan ini dengan mengacu kepada aturan-aturan mengenai investasi yang dapat dilakukan oleh pemerintah daerah. Terdapat empat perbandingan dalam analisis kelembagaan ini. Pemerintah Daerah Kota XYZ dapat melakukan investasi jangka panjang yakni pada perbandingan kesatu, kedua, dan ketiga, serta dapat melakukan investasi jangka pendek pada perbandingan keempat, selagi semua perbandingan dapat memberikan manfaat ekonomi seperti meningkatkan Pendapatan Asli Daerah (PAD), memberikan manfaat sosial seperti pelayanan kepada masyarakat, ataupun manfaat lainnya. Investasi pada sektor perbankan dapat mendatangkan manfaat ekonomi, manfaat sosial, dan manfaat lainnya sehingga sesuai dengan empat perbandingan tersebut. Tujuan dari kerja sama dengan pihak ketiga (penyertaan modal) yakni untuk pembiayaan fasilitas publik dalam rangka peningkatan pelayanan daerah. Investasi pada empat perbandingan ini dapat memberikan PAD. Yang termasuk ke dalam investasi jangka pendek adalah perbandingan keempat yakni tabungan, deposito, dan obligasi pemerintah, sesuai dengan karakteristik investasi jangka pendek. Hampir seluruh perbankan memiliki saham pada reksadana, namun hal ini tidak dapat dimasukkan ke dalam perbandingan karena memiliki rlsiko yang tinggi, walaupun dengan tingkat pengembalian yang tinggi juga (high risk high return).

Investasi jangka panjang yang dimaksudkan dalam peraturan adalah membeli surat berharga pada suatu badan usaha untuk menambah kepemilikan dan menjaga hubungan baik, seperti yang telah dilakukan Pemerintah Kota XYZ pada Bank Jabar Banten (perbandingan kesatu). Investasi jangka panjang seperti penanaman modal dalam bentuk saham hanya dapat dilakukan pada Badan Usaha Milik Daerah (BUMD), pada sektor perbankan seperti penyertaan modal pada Bank Jabar Banten yang terkait adalah perbandingan kesatu sedangkan pada perbandingan kedua dan ketiga tidak memenuhi kriteria. Untuk simpanan deposito (investasi jangka pendek) yakni perbandingan keempat, hanya dilakukan pada bank yang sehat, memenuhi aspek kelayakan finansial. Investasi permanen juga dapat dilakukan pada pembelian Surat Utang Negara (perbandingan keempat) yang hasilnya bertujuan untuk membantu pemberdayaan masyarakat.

\section{III.2.Posisi Modal dan Saham Bank Jabar Banten (Bank BJB) Sebelum IPO}

Sesuai dengan Peraturan Daerah Provinsi Daerah Tingkat I Jawa Barat No. 22 Tahun 1998 tanggal 14 Desember 1998, yang telah memperoleh pengesahan dari Menteri Dalam Negeri Republik Indonesia dalam Surat Keputusannya No. 584.32-027 tanggal 13 Januari 1999 dan telah diundangkan dalam Lembaran Daerah Provinsi Daerah Tingkat I Jawa Barat No. 3 tahun 1999 Seri D tanggal 26 Januari 1999 dibuat dihadapan Ny. Poppy Kuntari Sutresna, S.H., Notaris di Bandung, yang telah diumumkan dalam Tambahan No. 2811 Berita Negara Republik Indonesia No. 39 tanggal 14 Mei 1990, 
modal dasar Perseroan adalah sebesar Rp 250.000.000.000,- (dua ratus lima puluh miliar Rupiah) yang terbagi dalam dua jenis saham yaitu Saham Seri A sebanyak 20.000.000 (dua puluh juta) lembar saham dan Saham Seri B sebanyak 5.000.000 (lima juta) lembar saham, masing-masing saham dengan nilai nominal sebesar Rp 10.000,(sepuluh ribu rupiah) per lembar saham. Dari modal dasar tersebut telah ditempatkan dan disetor penuh sebanyak 9.363 .400 (sembilan juta tiga ratus enam puluh tiga ribu rupiah empat ratus) lembar saham atau senilai Rp93.634.000.000,-. Pemegang saham Perseroan terdiri dari Pemerintah Provinsi Jawa Barat, Pemerintah Kota/Kabupaten se Jawa Barat, dan Pemerintah Kota/Kabupaten se-Banten.

Perseroan meningkatkan modal disetor menjadi sejumlah 10.997 .081 saham atau sebesar Rp 109.970.810.000,- untuk tahun buku 1999 pada tahun 2000. Pada tahun 2001 terjadi peningkatan modal dasar Perseroan dari semula sebesar Rp250.000.000.000,- (dua ratus lima puluh juta miliar Rupiah) menjadi sebesar Rp1.000.000.000.000,- (satu triliun rupiah) dan peningkatan modal ditempatkan dan disetor Perseroan sebesar Rp190.201.210.000,- (seratus sembilan puluh miliar dua ratus satu juta dua ratus sepuluh ribu Rupiah). Untuk tahun 2002 dan 2003 tidak terjadi peningkatan modal Perseroan.

Pada tahun 2004, Perseroan meningkatkan modal dasar perseroan dari semula sebesar Rp1.000.000.000.000,- (satu triliun Rupiah) menjadi sebesar Rp2.000.000.000.000,- (dua triliun Rupiah) dan penambahan modal disetor Perseroan dari sebesar Rp509.368.403.638,88 (lima ratus sembilan puluh tiga ratus enam puluh delapan juta empat ratus tiga ribu enam ratus tiga puluh delapan Rupiah delapan puluh delapan sen) menjadi Rp684.141.163.63,84 (enam ratus delapan puluh empat miliar seratus empat puluh satu juta seratus enam puluh tiga ribu tujuh ratus enam puluh tiga Rupiah delapan puluh empat sen). Dengan adanya peningkatan modal disetor, pemegang saham Perseroan menjadi terdiri dari Pemerintah Provinsi Jawa Barat, Pemerintah Kota/Kabupaten se-Jawa Barat, Pemerintah Provinsi Banten, dan Pemerintah Kota/Kabupaten se-Banten. Perseroan meningkatkan modal ditempatkan dan modal disetor Perseroan dari semula sebesar 68.414.105 (enam puluh delapan juta empat ratus empat belas ribu seratus lima) saham atau senilai Rp 684.141.050.000 (enam ratus delapan puluh empat miliar seratus empat puluh satu juta lima puluh ribu Rupiah) menjadi sebanyak 86.134.245 (delapan puluh enam juta seratus tiga puluh empat ribu dua ratus empat puluh lima) saham atau senilai Rp 861.342.450.000,(delapan ratus enam puluh satu miliar tiga ratus empat puluh dua juta lima ratus enam puluh tiga ribu seratus empat puluh sembilan rupiah delapan puluh empat sen) pada tahun 2005.

Untuk tahun 2006 terjadi lagi peningkatan modal dasar Perseroan menjadi Rp 4.000.000.000.000,- (empat miliar rupiah) dari yang sebelumnya Rp2.000.000.000,(dua miliar Rupiah) dan peningkatan modal disetor sebesar Rp211.692.276.850,16 (dua ratus sebelas miliar enam ratus sembilan puluh dua juta dua ratus tujuh puluh enam ribu delapan ratus lima puluh koma enam belas Rupiah) dari semula Rp861.342.563.149,84 (delapan ratus enam puluh satu miliar tiga ratus empat puluh dua juta lima ratus enam puluh tiga ribu seratus empat puluh sembilan koma delapan puluh empat Rupiah) menjadi Rp1.073.034.840.000,- (satu triliun tujuh puluh tiga miliar tiga puluh empat juta delapan ratus empat puluh ribu Rupiah). Dan pada tahun 
2007 terjadi peningkatan modal disetor dan ditempatkan menjadi Rp1.264.475.880.349,84 (satu triliun dua ratus enam puluh empat miliar empat ratus tujuh puluh lima juta delapan ratus ratus delapan puluh ribu tiga ratus empat puluh sembilan Rupiah delapan puluh empat sen). Tahun 2008 tanggal 31 Januari 2008, yang isinya sehubungan dengan (i) pengubahan nilai nominal saham perseroan dari semula sebesar Rp10.000,- (sepuluh ribu rupiah) per saham, dan (ii) peningkatan modal ditempatkan dan modal disetor Perseroan dari semula sebesar Rp1.264.475.770.000,(satu triliun dua ratus enam puluh empat juta empat ratus tujuh puluh lima ribu tujuh ratus tujuh puluh ribu Rupiah) menjadi Rp1.495.597.116.250,- (satu triliun empat ratus sembilan puluh lima miliar lima ratus sembilan puluh tujuh juta seratus enam belas ribu dua ratus limapuluh Rupiah).

Sedangkan untuk tahun 2009, Perseroan meningkatkan modal ditempatkan dan modal disetor Perseroan sebesar Rp45.503.409.250,- (empat puluh lima miliar lima ratus tiga juta empat ratus sembilan ribu dua ratus lima puluh Rupiah) atau 182.013.637 (seratus delapan puluh dua juta tiga belas ribu enam ratus tiga puluh tujuh) saham Seri A.

Sebagai pemegang saham, Kota XYZ mulai menanamkan sahamnya terhadap Bank BJB pada tahun 2002 sebanyak 64.549 lembar saham seri A dengan nilai nominal per saham sebesar Rp10.000,00 atau setara dengan Rp640.590.000,00. Dari tahun ke tahun Pemerintah Daerah Kota XYZ terus melakukan peningkatan penanaman modal terhadap Bank Jabar Banten, sehingga pada Juli 2010 Pemerintah Daerah Kota XYZ memiliki sebanyak 89.581.968 lembar saham dengan nilai nominal sebesar Rp 250 per saham atau setara dengan Rp22.395.492.000. Perkembangan penanaman saham Pemerintah Daerah Kota XYZ pada Bank Jabar Banten dapat dilihat pada Gambar 2:

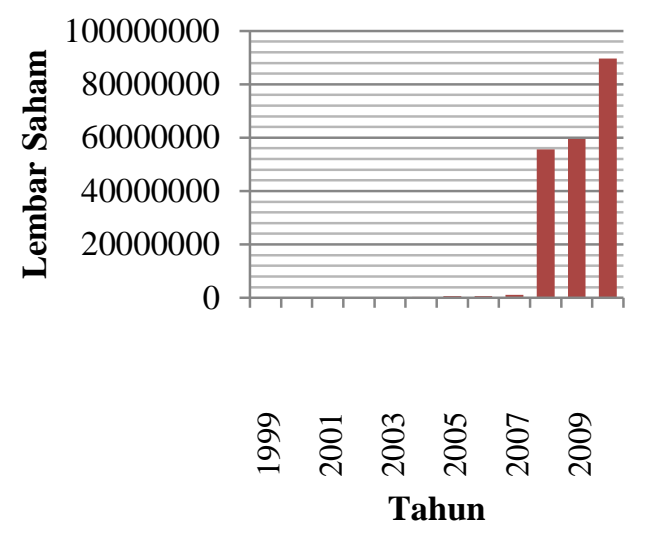

Gambar 2. Grafik Kepemilikan Pemerintah Daerah Kota XYZ

\section{III.3.Kebijakan Saham Setelah IPO}

Penjamin Pelaksana Emisi Efek dan Para Emisi Efek atas nama Perseroan dengan ini melakukan Penawaran Umum sebesar 2.424.072.500 (dua miliar empat ratus dua puluh empat juta tujuh puluh dua ribu lima ratus) saham baru yang merupakan Saham Atas Nama Seri B atau sebesar 25\% (dua puluh lima persen) dari modal ditempatkan dan disetor dengan nilai nominal Rp250,- (dua ratus lima puluh rupiah) setiap saham, 
yang ditawarkan kepada masyarakat dengan harga Penawaran Rp600,- (enam ratus rupiah) setiap saham, yang harus dibayar penuh pada saat mengajukan Formulir Pemesanan Pembelian Saham ("FPPS"). Nilai saham yang ditawarkan dalam Penawaran Umum secara keseluruhan adalah sebesar Rp1.454.443.500.000,- (satu triliun empat ratus lima puluh empat miliar empat ratus empat puluh tiga juta lima ratus ribu rupiah).

Bersamaan dengan pencatatan sebesar 2.424.072.500 (dua miliar empat ratus dua puluh empat juta tujuh puluh dua ribu lima ratus) saham baru yang merupakan saham biasa atas nama Seri B yang ditawarkan dalam Penawaran Umum ini atau sebesar $25 \%$ (dua puluh lima persen), Perseroan atas nama Pemegang saham Pendiri akan mencatatkan 7.175.255.754 (tujuh miliar seratus tujuh puluh lima juta dua ratus lima puluh lima ribu tujuh ratus lima puluh empat) saham Seri A sehingga jumlah seluruh saham yang akan dicatatkan pada BEI berjumlah 9.599.328.254 (sembilan miliar lima ratus sembilan puluh sembilan juta tiga ratus dua puluh delapan ribu dua ratus lima puluh empat) saham atau 99\% (sembilan puluh sembilan persen) dari seluruh jumlah Modal Ditempatkan dan Disetor Penuh setelah Penawaran Umum yang terdiri dari 74\% (tujuh puluh empat persen) dari Modal Ditempatkan dan Disetor Penuh yang berupa Saham Seri A dan 25\% (dua puluh lima persen) dari Modal Ditempatkan dan Disetor Penuh saham biasa atas nama Seri B. Sedangkan sejumlah 96.962.912 (sembilan puluh enam juta sembilan ratus enam puluh dua ribu sembilan ratus dua belas) saham atau 1\% (satu persen) saham milik Pemegang Saham Pendiri tidak dicatatkan guna memenuhi Peraturan Pemerintan No.29 Tahun 1999 (“PP No.29") tentang Pembelian Saham Bank Umum. Dari jumlah saham yang akan ditawarkan sebanyak-banyaknya $10 \%$ (sepuluh persen) akan dijatahkan kepada karyawan dan Manajemen Perseroan melalui Program EMSA (Employee and Management Stock Allocation) dengan Harga Penawaran.

Sebagai salah satu pemegang saham BANK BJB, Pemerintah Daerah Kota XYZ mulai menanamkan saham terhadap Bank Jabar banten mulai tahun 2002 hingga sekarang dengan jumlah yang terus meningkat. Pemerintah Daerah Kota XYZ sebelum IPO pada Juli 2010 memiliki saham sebesar 1,23\%, setelah IPO saham Pemerintah Daerah Kota XYZ di Bank Jabar Banten mengalami penurunan menjadi 0,92\%. Setelah IPO ini status saham Seri A Pemerintah Daerah kota XYZ tetap sama. Saham Seri A tetap hanya dimiliki oleh Pemerintah Kabupaten, Pemerintah Kota, Pemerintah Provinsi. Saham seri A memiliki kewenangan untuk memberikan keputusan dalam RUPS sedangkan Saham seri B hanya bersifat untuk memberikan masukan. Jika ada pelepasan saham baru ke masyarakat, maka Pemerintah akan mendapatkan penawaran terlebih dahulu dari Bank Jabar Banten sehingga Pemerintah dapat memutuskan akan menambah kepemilikan saham lagi atau tidak.

Untuk kebijakan deviden yang diberikan Bank BJB terhadap pemegang saham, Perseroan akan membayarkan dividen tunai minimum 40,00\% dari laba bersih setiap tahunnya dimulai dari tahun buku 2010, yang besarnya akan diputuskan melalui RUPS berdasarkan rekomendasi Direksi. Keputusan untuk membayar deviden tergantung pada laba, kondisi keuangan, likuiditas, kepatuhan terhadap peraturan perundangundangan dan faktor-faktor lain yang dianggap relevan oleh Direksi Perseroan setelah memperoleh persetujuan RUPS. 
Dana hasil IPO akan digunakan untuk ekspansi kredit perseroan (80\%), pembukaan kantor cabang baru (10\%), dan pengembangan teknologi informasi (10\%). Perseroan juga menetapkan kebijakan dividen minimal sebesar $40 \%$ dari laba bersih perseroan. Pembagian dividen dipastikan akan dimulai untuk tahun buku 2010. Perseroan menunjuk PT CIMB Securities dan PT Bahana Securities sebagai penjamin emisi IPO. Kapitalisasi pasar PT Bank BJB Tbk sebesar Rp5,759 triliun. P/E ratio industri per 6 Juli 2010 sebesar 17,01 kali dan PBV industri per 6 Juli 2010 sekitar 2,05 kali.

\section{III.4. Kinerja Bank Jabar Banten}

Kinerja BANK BJB mengalami peningkatan dari sejak berdiri pada tahun 1961 hingga sekarang. Hal ini terkait dengan strategi yang digunakan oleh perusahaan dalam menjalankan perusahaan. Hasil analisis terhadap strategi menunjukkan bahwa dalam penyusunan perencanaan penyertaan modal disusun berdasarkan matriks IE. Matriks IE menghasilkan strategi pertumbuhan. IE (Internal-Eksternal) Matriks: memosisikan organisasi ke dalam matriks dengan EFE (baris) dan IFE (kolom) dengan 3 ukuran, kuatsedang-lemah. Umumnya matriks ini digunakan untuk menilai posisi bersaing sebuah organisasi atau sebuah unit di dalam perusahaan. Posisi ini akan menentukan strategi dan keputusan di dalam perusahaan.

Dalam kasus pengembangan usaha Bank BJB, matriks IE digunakan untuk mengetahui posisi bersaing BANK BJB dalam persaingan pengembangan usaha. Posisi ini penting untuk menentukan posisi strategi yang akan ditetapkan. Secara umum, matriks ini menghasilkan tiga posisi strategi yaitu:

1. Strategi Pertumbuhan. Organisasi yang berada pada sel I, II, dan IV dapat digambarkan sebagai grow dan build. Strategi-strategi yang cocok bagi organisasi ini adalah strategi intensif.

2. Strategi Stabilitas. Organisasi yang berada pada sel-sel III, V, atau VII paling baik dikendalikan dengan strategi hold dan maintain.

3. Strategi Penciutan. Organisasi yang berada pada sel-sel VI, VIII, atau IX dapat menggunakan strategi harvest atau divestiture.

Hasil analisis IFE dan EFE menunjukkan bahwa skor bobot faktor internal adalah 2,8 dan skor bobot faktor eksternal adalah 2,94, artinya tingkat reaksi atau respons perusahaan terhadap pengaruh dari faktor internal terhadap penyertaan modal adalah rata-rata dan reaksi dari faktor internal terhadap penyertaan modal adalah sedang.

Kombinasi faktor eksternal dan internal tersebut pada matriks IE menghasilkan posisi strategi stabilitas (Hold and Maintain). Strategi Hold and Maintain ini menunjukkan bahwa perusahaan harus mempertahankan kondisi saat ini untuk menghadapi tantangan yang semakin besar. Tantangan tersebut adalah pengembangan usaha yang diarahkan kepada upaya investasi, agar mampu membangun daya tarik perusahaan di mata penanam modal untuk melakukan investasi. Oleh karena itu, salah satu yang harus diperhatikan adalah posisi strategi Bank BJB saat ini tepat dengan menjaga stabilitas pengembangan usaha di Bank BJB, antara lain upaya mempertahankan kinerja perusahaan dan mengembangkan pasar.

Uraian di atas menunjukkan bahwa posisi kompetitif perusahaan di dalam industri membuat perusahaan harus selalu berupaya mendapatkan dana (modal) yang ingin dicapai. Kekuatan perusahaan mampu memperoleh modal pada industri ini, jika semua 
kondisi terpenuhi. Posisi strategi Hold and Maintain menunjukkan bahwa Pemerintah Kota XYZ layak menempatkan sahamnya di BANK BJB pada tahun ini.

Untuk dapat merealisasikan target dana yang ditetapkan, maka yang diperlukan perusahaan adalah menentukan langkah-langkah operasional yang tepat dalam mencapai target dana tersebut. Langkah-langkah tersebut dapat dianalisis dengan menggunakan matriks SWOT.

\section{III.5. Hasil Analisis SWOT}

Bank BJB adalah salah satu BUMD yang bergerak di sektor perbankan. Umumnya setiap unit bisnis harus memantau kekuatan lingkungan makro yang menjadi penentu (demografi-ekonomi, teknologi, politik-hukum, dan sosial-budaya), dan pelaku lingkungan mikro utama (pelanggan, pesaing, saluran distribusi, pemasok) yang berdampak pada kemampuannya memperoleh laba (Kotler, 2005). Dari empat perbandingan yang disajikan, yang hanya sesuai dengan analisis kelembagaan hanya perbandingan kesatu dan keempat. Maka, pada tahap ini perbandingan ke-1 (Penyertaan Modal terhadap BANK BJB) dan perbandingan Ke-4 (Penyertaan Modal terhadap Produk Perbankan lainnya) dikaji dari sektor internalnya (kekuatan, kelemahan) dan sektor eksternalnya (peluang dan ancaman) menggunakan Analisis SWOT, seperti yang disajikan di bawah ini:

Analisis SWOT pada perbandingan ke-1 (Penyertaan Modal terhadap Bank BJB) antara lain:

1. Kekuatan

- Bank Terbaik kategori Pembangunan Daerah

- Pertumbuhan penghimpunan dana masyarakat yang baik

- Pertumbuhan laba yang meningkat.

- Memiliki nama dan citra perusahaan yang berkinerja baik

- Simpanan yang berhasil dihimpun oleh Bank BJB Unit merupakan modal untuk melakukan ekspansi

- Potensi pasar yang masih besar akan dapat meningkatkan jumlah nasabah baru

- Struktur organisasi yang menunjang efektifitas operasional.

2. Kelemahan

- Promosi yang masih minim terhadap sektor publik

- Kurangnya tenaga khusus promosi

- Operasional bisnis perbankan belum berskala nasional

- Skala permodalan sebagian besar masih lingkup pemerintah.

- Pembinaan nasabah kurang selektif, seperti kurangnya kecepatan dalam pelayanan.

- Kurangnya Kantor Cabang Pembantu (KCP) dan jaringan ATM yang memadai

- Kualitas SDM yang masih berkategori rata-rata

- Produk yang ditawarkan masih terbatas

- Belum adanya program komputerisasi tersentral dan penggunaan jaringan komunikasi khusus (seperti VSAT, atau Jaringan List Line Fiber Optic). Sehingga memungkinkan dilakukannya real time transaksi, online system, phone banking maupun internet banking dengan program tersebut

- Keberpihakan kepada pengusaha kecil dan mikro yang masih minim. 
3. Peluang

- Penggunaan teknologi dalam pelayanan

- Meningkatnya konsumsi masyarakat akan perbankan

- Menggencarkan promosi melalui media massa untuk meningkatkan minat masyarakat terhadap Bank BJB

- Perzinan yang mendukung dalam aspek hukum untuk perkembangan perusahaan

- Potensi dana masyarakat yang sangat besar di Jawa Barat

- Kebijakan Pemerintah dan Bank Indonesia yang mendukung

- Memiliki dukungan modal dan komitmen pemegang saham yang kuat

- Kondisi ekonomi nasional mulai menunjukan perbaikan dengan dibuktikan oleh pertumbuhan ekonomi yang mulai positif pada beberapa tahun terakhir

- Perhatian pemerintah terhadap kemajuan pengusaha kecil masih besar dengan banyaknya bantuan dari pemerintah baik berupa dana maupun manajemen

- Potensi pasar terhadap pengusaha di tingkat kecamatan masih banyak yang dapat digali

- Kepercayaan terhadap nama atau citra BANK BJB di masyarakat masih cukup besar.

4. Ancaman

- Adanya revisi terhadap undang-undang penanaman modal Pemda sehingga dapat bergulir ke bank swasta

- Ilmu Pengetahuan dan Teknologi bank pesaing lebih canggih dan mutakhir

- Pendekatan dari bank pesaing yang memberikan keunggulan produk atau layanan prima

- Krisis keuangan global dan nasional yang dapat mempengaruhi sektor perbankan

- Arus globalisasi akan mempengaruhi timbulnya bank-bank asing yang membiayai usaha mikro

- Banyaknya bank pesaing yang mulai melakukan pembiayaan mikro seperti Bank BNI, Bank Danamon, BRI, Koperasi dan BPR

- Menurunkan daya beli masyarakat akibat krisis moneter dan kenaikan harga BBM pada periode yang lalu dan saat ini masih terasa dan untuk menaikkannya sangat tergantung pada perbaikan perekonomian kita.

\section{Analisis Finansial}

Analisis finansial mencakup perbandingan EPS (Earning Per Share), ROE (Return On Equity), dan tingkat suku bunga. Pemerintah Daerah Kota XYZ dapat membeli obligasi pemerintah sebagai salah satu investasi jangka panjang yang memberikan nilai suku bunga yang tinggi seperti Sukuk Negara Ritel Seri SR-001 yang memberikan suku bunga sebesar $12,00 \%$. Namun, pembelian obligasi pemerintah ini harus bersifat permanen yakni tidak berpindah tangan atau diperjualbelikan di pasar sekunder, hanya boleh diperjualbelikan di pasar primer. 
Tabel 1. Perbandingan EPS dari BANK BJB dan Pesaingnya

\begin{tabular}{lccccccc}
\hline \multirow{2}{*}{ Bank } & \multicolumn{3}{c}{ EPS (dalam Rupiah) } & Rata-rata \\
\cline { 2 - 6 } & 2005 & 2006 & 2007 & 2008 & 2009 & 2010 & EPS \\
\hline BCA & 213 & 345 & 183 & 236 & 209 & 251 & 239.50 \\
Danamon & 407.71 & 268.91 & 423.27 & 303.7 & 186.36 & 262.12 & 308.68 \\
Permata & 38.1 & 40.23 & 64.45 & 58.43 & 62.01 & 67.33 & 55.09 \\
Panin & 31.48 & 37.46 & 42.32 & 34.6 & 41.01 & 46.87 & 38.96 \\
BANK BJB & - & 29.58 & 69.56 & 91.82 & 113.75 & - & 76.18 \\
BNI & 106 & 145 & 64 & 80 & 163 & 193 & 125.17 \\
BRI & 321.7 & 355.62 & 403.64 & 496.99 & 442.17 & 555.25 & 429.23 \\
\hline
\end{tabular}

Tabel 2. Perbandingan EPS dari Bank BJB dan pesaingnya

\begin{tabular}{cccccccc}
\hline \multirow{2}{*}{ Bank } & \multicolumn{9}{c}{ ROE (\%) } & \multicolumn{2}{c}{ Rata-rata } \\
\cline { 2 - 6 } BCA & 2005 & 2006 & 2007 & 2008 & 2009 & 2010 & ROE \\
Danamon & 27,35 & 29,07 & 26,74 & 30,16 & 32,00 & 32,25 & 29,60 \\
Permata & 24,20 & 15,10 & 22,90 & 22,30 & 14,90 & 19,70 & 19,85 \\
Panin & 14,30 & 13,10 & 18,10 & 12,40 & 18,02 & 25,10 & 16,84 \\
BANK BJB & 14,14 & 14,27 & 13,98 & 10,16 & 10,40 & 15,48 & 13,07 \\
BNI & 23,54 & 22,28 & 19,58 & 25,54 & 28,09 & 31,70 & 25,12 \\
BRI & 12,64 & 22,61 & 8,03 & 9,01 & 16,34 & 25,12 & 15,63 \\
\hline
\end{tabular}

Dari sisi EPS, seperti yang ditunjukkan pada Tabel 1 bahwa rata-rata EPS tertinggi diraih oleh BRI yakni Rp. 429,23 dan yang terendah dimiliki oleh Bank Panin sebesar 38,96. Hal ini menunjukkan bahwa BRI memberikan rata-rata pengembalian dari saham yang ditanamkan lebih besar dibandingkan keenam bank lainnya. Sedangkan EPS dari Bank BJB menempati peringkat kelima dari ketujuh bank. Hal ini terlihat bahwa sebagai bank yang masih berskala daerah dan baru melakukan IPO, Bank BJB dapat bersaing dengan memberikan nilai rata-rata EPS sebesar $R p$ 76,18,dibandingkan dengan bank yang sudah berskala nasional maupun internasional seperti Bank ANZ Panin.

Untuk rata-rata ROE tertinggi diraih juga oleh BRI yakni sebesar $34.40 \%$ dan terendah pada Bank Panin. Dilihat dari sisi ROE bahwa pada hampir semua bank mengalami tingkat ROE yang fluktuatif, namun pada BNI dan BCA cenderung naik dari tahun 2007-2010 seperti yang disajikan pada Tabel 2. Dilihat dari ROE Bank BJB, terlihat jelas bahwa Bank BJB memiliki rata-rata tertinggi kedua setelah BRI, mengalahkan bank lainnya seperti Danamon dan BNI. Dari hal ini, maka pengembalian atas ekuitas Bank BJB berkategori baik dan dapat bersaing dengan bank lainnya yang berskala nasional. Dengan ROE yang tinggi maka akan berdampak pada peningkatan laba yang akan diperoleh perusahaan sehingga akan berdampak pula terhadap deviden. Deviden yang dibagikan kepada para pemegang saham adalah minimum $40 \%$ dari laba yang diperoleh perusahaan. Maka, ROE yang tinggi akan meningkatkan deviden. 
Selanjutnya dilakukan analisis tren dengan metode kuantitatif pada ROE (\%) dan EPS (Rupiah) pada BANK BJB Data historis yang digunakan adalah tahun 2006 sampai dengan 2010. Untuk peramalan EPS, bentuk persamaan yang dihasilkan merupakan hubungan antara variabel dependen (Yt) yang berupa EPS (Rp) dan variabel independen ( $t$ ) berupa deret waktu (tahun), sedangkan untuk ROE variabel dependen $(\mathrm{Yt})$ berupa ROE (\%) dan variabel independen $(\mathrm{t}$ ) yang berupa deret waktu (tahun). Tampilan perhitungan analisis tren menggunakan program komputer Minitab untuk EPS dapat dilihat pada Gambar 3.

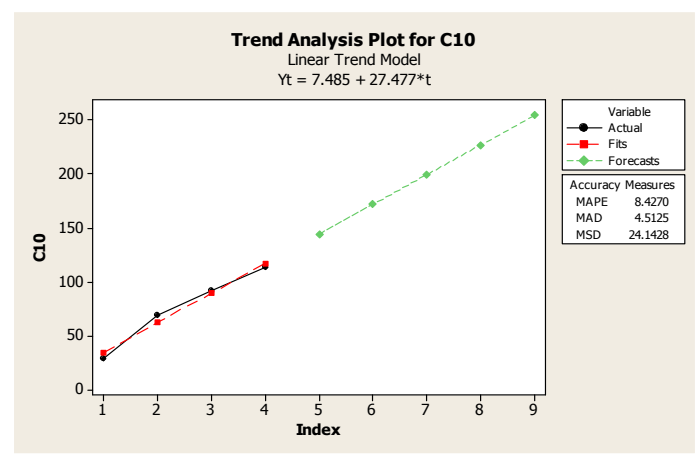

Gambar 3. Forecasting untuk EPS Bank BJB

Dari data yang telah diperoleh pada Gambar 3, sehingga model matematis untuk peramalan EPS adalah $\mathrm{Yt}=7,485+27,477 *$ t dengan nilai kesalahan peramalan, yakni MAD $=4,5125, M S D=24,1428$, MAPE $=8,4270$. Model matematis tersebut dapat meramalkan EPS untuk masa yang akan datang. Dari data pada Tabel 3, menunjukkan peramalan untuk EPS BANK BJB lima tahun ke depan akan mengalami peningkatan, sehingga dengan keadaan EPS yang meningkat dapat menguntungkan para pemegang saham Bank BJB.

Tabel 3. Peramalan EPS Bank BJB Tahun 2010 - 2014

\begin{tabular}{ll}
\hline Tahun & Forecast (Rupiah) \\
\hline 2010 & 144,870 \\
2011 & 172,347 \\
2012 & 199,824 \\
2013 & 227,301 \\
2014 & 254,778 \\
\hline
\end{tabular}

Sedangkan untuk peramalan ROE diperoleh model matematis $\mathrm{Yt}=$ $25.924+1.04886 * t$ dengan nilai $\mathrm{MAPE}=2.7903, \mathrm{MAD}=0.77686$, dan $\mathrm{MSD}=1.22786$ seperti yang terlihat pada Gambar 4. 


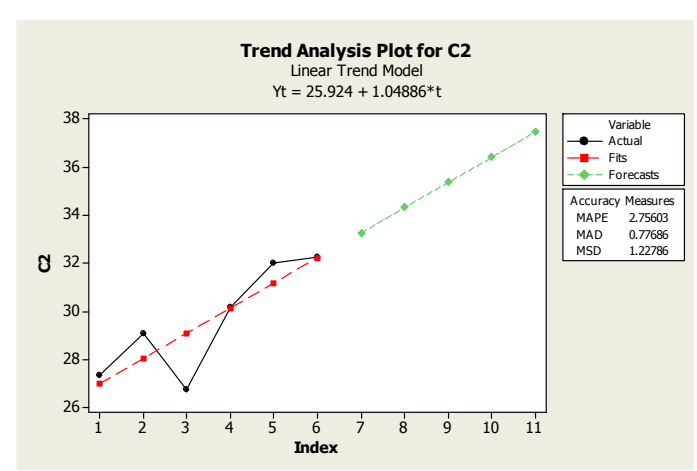

Gambar 4. Forecasting untuk ROE Bank BJB

Sehingga dari model matematis yang diperoleh dapat meramalkan ROE BANK BJB untuk masa yang akan datang yakni untuk tahun 2011 sampai dengan tahun 2015, seperti yang ditunjukkan pada Tabel 13 .

Tabel 4. Peramalan ROE Bank BJB Tahun 2010 - 2014

\begin{tabular}{cc}
\hline Tahun & Forecast (\%) \\
\hline 2011 & 33,2660 \\
2012 & 34,3149 \\
2013 & 35,3637 \\
2014 & 36,4126 \\
2015 & 37,4614 \\
\hline
\end{tabular}

Data peramalan ROE Bank BJB menunjukkan untuk peramalan lima tahun ke depan yakni sampai tahun 2015, ROE Bank BJB akan mengalami kenaikan walaupun kenaikan tersebut hanya sekitar $1 \%$ per tahun. Dengan nilai ROE yang diprediksikan mengalami peningkatan, hal ini akan berdampak terhadap laba yang diperoleh BANK BJB sehingga berdampak juga terhadap deviden yang diberikan kepada para pemegang saham BANK BJB.

\section{Kesimpulan}

Melihat adanya otonomi daerah yang diberikan Pemerintah Daerah Kota XYZ, pemerintah dapat memanfaatkan otonomi daerah dengan tetap melihat peraturan (undang-undang) yang ada. Dilihat dari peraturan yang terkait dan dianalisis kelembagaan, Pemerintah Daerah Kota XYZ dapat melakukan investasi jangka pendek yakni investasi pada produk perbankan di bank sehat yakni deposito dan tabungan (simpanan) dan untuk investasi jangka panjang dapat melakukan penempatan modal pada Saham Seri A dan Saham Seri B hanya di Bank BJB sebagai BUMD, sepanjang bersifat investasi jangka panjang, tidak diperjualbelikan (bersifat sebagai investasi permanen juga). Untuk investasi jangka pendek, Pemerintah Daerah Kota XYZ dapat melakukan investasi pada produk perbankan di semua yang bank sehat yakni seperti deposito, tabungan (simpanan), dan obligasi pemerintah.

Dengan berubahnya status Bank BJB menjadi perseroan terbuka dan melakukan IPO, membuat Bank BJB terus meningkatkan prestasinya untuk dapat bersaing dengan bank lainnya dan meningkatkan kepercayaan masyarakat. Dilihat dari lingkungan eksternal dan internalnya Bank BJB memiliki skor bobot faktor internal sebesar 2,8 dan 
eksternalnya sebesar 2,94. Hal ini berarti tingkat atau eksternal terhadap penyertaan modal adalah sedang dan menghasilkan posisi Hold and Maintain yang menunjukkan bahwa perusahaan harus mempertahankan kondisi saat ini karena tantangannya semakin besar, sehingga bagi Pemerintah Kota XYZ layak menempatkan sahamnya di Bank BJB.

Untuk hal produk simpanan (tabungan dan deposito), BANK BJB masih memberikan bunga deposito terbesar yakni 8,75\% kepada Pemerintah Daerah Kota XYZ dibandingkan dengan perbankan lainnya. Di sisi lain, jika dilihat dari deviden per saham yang dibagikan, Bank BJB masih relatif lebih kecil dibandingkan dengan bank pesaing. Namun, Pemerintah Daerah Kota XYZ tetap hanya dapat melakukan penanaman saham hanya di Bank BJB. Di sisi lain, dilihat dari harga saham yang terus meningkat setelah terjadinya IPO membuat modal yang ditanamkan Kota XYZ menjadi terus bertambah.

Semenjak tahun 2002 sampai dengan saat ini, Pemerintah Daerah Kota XYZ telah menanamkan Saham Seri A di Bank BJB. Saham seri A yang dimiliki oleh Pemerintah Daerah Kota XYZ sebanyak 89.581 .968 lembar saham atau setara dengan Rp22.395.492.000 dengan presentase sebesar 0,92\% setelah IPO, yakni menurun dari 1,23\% sebelum terjadinya IPO. Dari keseluruhan analisis dapat disimpulkan bahwa penanaman investasi jangka panjang maupun jangka pendek layak dilakukan oleh Pemerintah Daerah Kota XYZ.

\section{DAFTAR PUSTAKA}

Kotler. P. 2005. Manajemen Pemasaran Jilid I. Jakarta : PT Indeks Kelompok Gramedia.

Mahmudi. 2010. Manajemen Keuangan Daerah. Jakarta : Erlangga

Pemerintah Republik Indonesia Nomor 58 tahun 2005 tentang Pengelolaan Keuangan Daerah.

Peraturan Menteri Dalam negeri Nomor 13 Tahun 2006 tentang Pedoman Pengelolaan Keuangan Daerah.

Peraturan Pemerintah Republik Indonesia Nomor 105 Tahun 2000 tentang Pengelolaan dan Pertanggungjawaban Keuangan Daerah.

Undang-undang Republik Indonesia Nomor 22 tahun 1999 tentang Pemerintahan Daerah.

Undang-undang Republik Indonesia Nomor 25 tahun 1999 tentang Perimbangan Keuangan Antara Pemerintah Pusat dan Daerah.

Undang-undang Republik Indonesia Nomor 32 tahun 2004 tentang Pemerintahan Daerah.

www.bankjabar.co.id. [27-29 Desember 2010].

www.bi.go.id. [2 Desember 2010].

www.bni.co.id. [29 November 2010].

www.danamon.co.id. [29 November 2010].

www.panin.co.id. [30 November 2010].

www.permatabank.com. [3 November 2010]. 